\title{
Effect of pregnancy on packed cell volume and total white blood cells count among Sudanese pregnant women attending antenatal care at Ribat University Hospital (Khartoum state)
}

\author{
Wafa Mubarak M. Ahmed ${ }^{1}$, Abdurrahman Khalid², O. A. Musa ${ }^{3 *}$
}

\begin{abstract}
${ }^{1}$ Department of Physiology, Faculty of Medicine, Ibn Sina University, Khartoum, Sudan ${ }^{2}$ Department of Obstetrics and Gynecology, Ribat University Hospital, Khartoum, Sudan ${ }^{3}$ Department of Physiology, Faculty of Medicine, The National Ribat University, Khartoum, Sudan
\end{abstract}

Received: 05 December 2017

Accepted: 08 January 2018

\section{*Correspondence:}

Dr. O. A. Musa,

E-mail: omusa56@yahoo.co.uk

Copyright: () the author(s), publisher and licensee Medip Academy. This is an open-access article distributed under the terms of the Creative Commons Attribution Non-Commercial License, which permits unrestricted non-commercial use, distribution, and reproduction in any medium, provided the original work is properly cited.

\begin{abstract}
Background: During pregnancy the women undergo several structural and physiological changes almost in all body systems including the hematological profile. The main reported hematological change is the plasma expansion and haemodilution which affect the red blood cells(RBCs) and white blood cells (WBCs) count in addition to other hematological indices including packed cell volume (PCV). The objective of this study was to assess the effect of pregnancy on packed cell volume and white blood cells among Sudanese pregnant women and derive a formula for the normal values in pregnant women in relation to the packed cell volume.

Methods: An analytical case control study was conducted in Khartoum state, Sudan 2017. The study included20 Sudanese pregnant women in the second and third trimesters attending the antenatal care at The National Ribat university hospital and 20 Sudanese non-pregnant women in the same age group as control. A questionnaire was used to collect socio-demographic and clinical data. $5 \mathrm{ml}$ of venous blood was collected in a container containing EDTA. Complete blood count (CBC) was measured by using automated cell counter Sysmex.

Results: There was statistically significant decrease in PCV value during 2nd and 3rd trimesters of pregnancy compared to the non-pregnant control group with $\mathrm{p}$ values ( 0.00 and 0.04 respectively), and statistically significant increase in WBCs count during $2^{\text {nd }}$ and $3^{\text {rd }}$ trimesters of pregnancy compared to the non-pregnant control group with $\mathrm{p}$ values (0.04 and 0.00 respectively). Also, a progressive increase in WBCs count with gestational age was demonstrated (second trimester $6.65 \times 103 / \mathrm{uL}$, third trimester $7.43 \times 103 / \mathrm{uL}$ ). The results showed mean WBCs of $7.79 \times 103 / \mathrm{uL}$, when compared to the estimated values the results showed no significant difference with the mean WBCs in 2ndand 3rdtrimesters ( $\mathrm{p}$ value 0.06 and 0.39 respectively).

Conclusions: During pregnancy there was statistically significant decrease in PCV values, statistically significant increase in WBCs count and by considering the haemodilution factor there was a higher increase in WBCs count.
\end{abstract}

Keywords: Haemodilution, PCV, Sudanese pregnant women, WBCs

\section{INTRODUCTION}

Pregnancy is characterized by many hematological changes, which may appear to be pathological in the nonpregnant state. ${ }^{1,2}$ Many studies have identified the hematological profile of the pregnant woman as one of the factors affecting pregnancy and its outcome. ${ }^{2,3}$ During pregnancy, plasma expansion and haemodilution contribute to the majority of these changes, there is increase in plasma volume as well as in red cells and 
white blood cells volume. ${ }^{4-7}$ The total blood volume increases in order to supply the demands of the new vascular bed and also to compensate for blood loss occurring at delivery. ${ }^{1,6,8}$ Modifications in the production of red cells and changes in plasma volume has some effects on some of the hematological indices such as red blood cells count, packed cell volume, hemoglobin concentration, platelet count, and white blood cell count. ${ }^{4,6,9}$ Some of these are decreased like RBC and PLT counts partly as a result of the physiological haemodilution that occurs in pregnancy, while others are increased, such as the WBC count. ${ }^{4,5}$

Plasma volume in pregnancy was found to increase by about $10-15 \%$ at $6-12$ weeks of gestation then expands rapidly until 30-34 weeks. The total gain of plasma volume at term is about $1.5 \mathrm{~L}$ and results in a plasma volume of $4700-5200 \mathrm{~mL}, 30-50 \%$ above the nonpregnant women plasma. ${ }^{10-13}$ During pregnancy the total volume of circulating blood increases. ${ }^{7}$ Red blood cell mass was reported to increase by about $20-30 \%$ above non- pregnant levels by the end of pregnancy which is mainly driven by the increase in erythropoietin production. ${ }^{10,12,14}$ Therefore, the increase in plasma volume is more than the increase in the red blood cells. Consequently, the packed cell volume decreases due to the haemodilution. ${ }^{2,15-17}$ Regarding the white blood cells, many studies reported that pregnancy is usually associated with leukocytosis. . $^{3,12,18}$ It is mainly from neutrophilia, which is attributed to physiologic stress and it is known to increase with gestational age..$^{2,10,19,20}$ So during pregnancy the mean white blood cells counts of 10,000-16,000 cells/uL with an upper level as high as 29,000 cells/uL at labor were observed. ${ }^{2}$ The count falls to reach the normal non-pregnant range by the sixth day postpartum. ${ }^{10,11}$ Some researchers reported that in a woman with normal pregnancy, there is no change in the absolute lymphocyte count. ${ }^{10,20}$ The monocytes count tended to increase, while the basophiles and eosinophils count may slightly decrease. ${ }^{20}$ Also women with normal pregnancies can have a small number of immature cells in the peripheral circulation. . $^{210,12}$

\section{METHODS}

This was an analytical case control study conducted at The National Ribat University hospital, Khartoum, Sudan 2017 to assess the effect of pregnancy on PCV and WBCs count among Sudanese women. The study population included 20 Sudanese Pregnant women at second and third trimester aged between 18 to 40 years and 20 Control of Sudanese non-pregnant women at the same age group, those with acute infection or anemia were excluded. A questionnaire was used to collect the socio-demographic and clinical data including age, parity, trimester of pregnancy, history of infection, abortion or sever bleeding and use of medicines during current pregnancy. Consent was obtained from each individual participating in the study. $5 \mathrm{ml}$ of venous blood collected from each participant by a disposable needle in a container containing EDTA, complete blood count (CBC) was measured using automated cell counter Sysmex. Data was analyzed using the Statistical Package for Social Sciences (SPSS) computer program version 20(P value $\leq 0.05$ considered significant).

\section{RESULTS}

The study population comprised 20 pregnant women, 7 in $2^{\text {nd }}$ trimester and 13 in $3^{\text {rd }}$ trimester rand 20 non-pregnant women as control; all of them were within the child bearing age.

Table 1: PCV and WBCs in $2^{\text {nd }}, 3^{\text {rd }}$ trimesters.

\begin{tabular}{|lllll|}
\hline Parameters & & Mean \pm Std. Deviation & Minimum & Maximum \\
\hline \multirow{2}{*}{$\begin{array}{l}\text { Packed cell volume } \\
(\text { PCV) }\end{array}$} & Second trimester & $29.2500 \pm 2.83843$ & 27.00 & 33.40 \\
\hline $\begin{array}{l}\text { White blood cell count } \\
(\text { WBCs })\end{array}$ & Third trimester & $33.8313 \pm 3.79679$ & 26.50 & 40.90 \\
$\left(\times 10^{3} / \mathrm{uL}\right)$ parameters & Control & $37.3500 \pm 3.08041$ & 30.90 & 43.60 \\
\hline
\end{tabular}

From the analysis the mean values for the pregnant women in $2^{\text {nd }}$ trimester was as follows: PCV 29.25 \pm 2.83 , WBCs $6.65 \times 10^{3} / \mathrm{uL} \pm 0.8$ and the mean values for pregnant women in $3^{\text {rd }}$ trimester was as follows $\mathrm{PCV}$ $33.83 \pm 3.79$, WBCs $7.43 \times 10^{3} / \mathrm{uL} \pm 1.58$ compared to PCV $37.35 \pm 3.08$ and WBCs $4.67 \times 10^{3} / \mathrm{uL}$ in control (Table 1 ).

The results showed a statistically significant decrease in $\mathrm{PCV}$ in $2^{\text {nd }}$ and $3^{\text {rd }}$ trimesters with $\mathrm{p}$ values $(0.00$ and
0.04, respectively) when compared to non-pregnant (Table 1). There is also a statistically significant increase in WBCs in $2^{\text {nd }}$ and $3^{\text {rd }}$ trimesters with $\mathrm{P}$ values $(0.04$ and 0.00 , respectively) when compared to non-pregnant. Also, WBCs showed progressive increase with gestational age (Table 1). When the haemodilution effect on WBCs count was considered by applying the equation:

[Plasma (pregnant)/ plasma (control)]xWBCs (pregnant) 
where the ratio of the plasma in pregnant ladies to that of the non-pregnant was taken as the dilution factor, the results showed mean WBCs of $7.79 \times 10^{3} / \mathrm{uL}$, when compared with the estimated values the results showed significant difference with the mean WBCs in control group ( $\mathrm{p}$ value 0.00 ), no significant difference with the mean WBCs in $2^{\text {nd }}$ and $3^{\text {rd }}$ trimesters ( $\mathrm{p}$ value 0.006 and 0.39 , respectively). So, the mean WBCs value for pregnant women in the $3^{\text {rd }}$ trimester was more relevant to the value that was calculated by the equation (Figure 1).

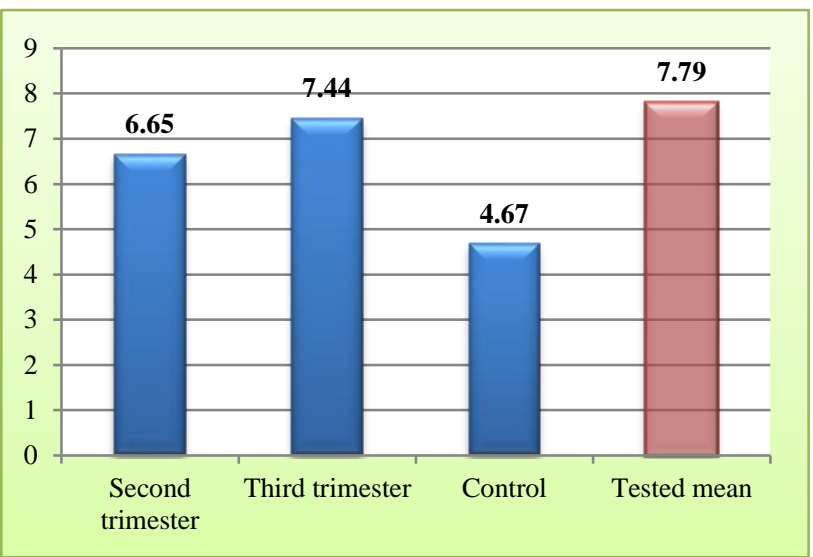

Figure 1: $2^{\text {nd }}$ and $3^{\text {rd }}$ trimester means $\mathrm{WBCs}$ and the estimated WBCs value of $7.79 \times 10^{3} / \mathrm{uL}$.

\section{DISCUSSION}

Pregnancy is a physiological state that is characterized by different hematological changes. In this study we assessed the changes of PCV and WBCs count among Sudanese pregnant women in comparison to Sudanese non-pregnant values. It showed a statistically significant decrease in the mean PCV values for pregnant women in 2nd and 3rd trimesters, (Table 1). This is mainly due to the increase of plasma volume during pregnancy that lead to haemodilution. These results are consistent with Purohit $\mathrm{G}$ in India, and Anberbir S in Ethiopia, Abbas RE study conducted in Sudan. ${ }^{2,4,15}$

This study showed a statistically significant increase in the mean WBCs in 2nd and 3rd trimesters of pregnancy in comparison to non-pregnant values (Table 1), WBCs showed progressive increase with gestational age. These results are consistent with Anberbir $\mathrm{S}$ in Ethiopia, Mohamed AO in Sudan, but contradictory with Abbas RE study in Sudan which showed that WBCs count were within normal values for both case and control. ${ }^{4,14,15}$ Leukocytosis during pregnancy may be due to physiological stress and hyper dynamic circulation.

During pregnancy Plasma volume was found to be increased by about $10-15 \%$ at 6-12 weeks of gestation then expands rapidly to reach about $30-50 \%$ at $30-34$ weeks which might have an effect on some of hematological indices including the WBCs count, so if we considered the difference in plasma percentage among pregnant and non-pregnant women and the effect of haemodilution to determine the actual values of WBCs during pregnancy the results showed a mean WBCs of $7.79 \times 10^{3} / \mathrm{uL}$ which is almost double the WBCs of the control, these results denote a direct relation between the PCV as a part of the haemodilution and the WBCs count during pregnancy. When the total WBCs were calculated in an extra $1.5 \mathrm{~L}$ of plasma it has reached: $7790 \times$ $1500000 \mathrm{uL}=11685 \times 10^{6}$ extra cells in pregnant ladies!! With consideration of the effect of the stress and hyper dynamic circulation, this still needs a big scale study to confirm and explain the factors leading to this huge increase in WBCs during pregnancy.

\section{CONCLUSION}

This study concluded that during pregnancy there was significant decrease in PCV values and a significant increase in WBCs in comparison to non-pregnant and by considering the haemodilution factor. It is highly recommended to include the PCV in the routine hematological blood test during pregnancy to consider the haemodilution factor that affects all hematological values. Further studies in Sudan with larger sample size and different pregnancy trimesters might show an accurate effect of haemodilution on blood cells and particularly WBCs count.

\section{ACKNOWLEDGMENTS}

The authors would like to thank all the volunteers that participated in this study, staff of the National Ribat university hospital, department of obstetrics and gynecology and the medical laboratory.

Funding: No funding sources

Conflict of interest: None declared

Ethical approval: The study was approved by the Institutional Ethics Committee

\section{REFERENCES}

1. Surabhi Chandra, Anil Kumar Tripathi, Sanjay Mishra, Mohammad Amzarul, and Arvind Kumar Vaish: Physiological Changes in Hematological Parameters During Pregnancy. Indian J Hematol Blood Transf. 2012;28(3):144-6.

2. Purohit G, Shah T, Harsoda JM. Hematological profile of normal pregnant women in Western India. Scholars J Appl Med ScI. 2015;3(6A):2195-9.

3. Akinbami AA, Ajibola SO, Rabiu KA, Adewunmi AA, Dosunmu AO, Adediran A ET AL. Hematological profile of normal pregnant women in Lagos, Nigeria. Int J Women's Health. 2013;5:22732.

4. Anberbir S, Hussein M, Tibebu M. Hematological profile of pregnant women attending antenatal care at Dilla University Referral Hospital, Dilla, Ethiopia: comparative cross sectional study. MSc research. October, 2016. 
5. Grathwohl KW, Bruns BJ, LeBrun CJ, Ohno AK, Dillard TA, Cushner HM. Does hemodilution exist? Effects of saline infusion on hematologic parameters in euvolemic subjects. Southren Med J. 1996 Jan;89(1):51-5.

6. Soma-Pillay $\mathrm{P}$, Nelson-Piercy C, Tolppanen H, Mebazaa A. Physiological changes in pregnancy. Cardiovasc J Afr. 2016 Mar-Apr; 27(2):89-94.

7. Miller JR, Keith NM, Rowntree LG. Plasma and blood volume in pregnancy. JAMA. 1915 Aug 28;65(9):779-82.

8. Elmugabil A, Rayis DA, Abdelmageed RE, Adam I, Gasim GI. High level of hemoglobin, white blood cells and obesity among Sudanese women in early pregnancy: a cross-sectional study. Future Sci OA. 2017 Apr 4;3(2):FSO182.

9. Van Buul EJ, Steegers EA, Jongsma HW, Eskes TK, Thomas CM, Hein PR. Hematological and biochemical profile of uncomplicated pregnancy in nulliparous women. Netherlands J Medic. 1995;46(2):73-85.

10. Hossain N, Paidas MJ. Hematologic Changes in Pregnancy. Research Gate. March 2011. Available at https://www.researchgate.net/publication/227697211 _Hematologic_Changes_in_Pregnancy

11. James TR, Reid HL, Mullings AM. Are published standards for haematological indices in pregnancy applicable across populations: an evaluation in healthy pregnant Jamaican women. BMC Pregnancy Childbirth. 2008 Feb 28;8(1):8.

12. James TR, Reid HL, Mullings AM. Are published standards for haematological indices in pregnancy applicable across populations: an evaluation in healthy pregnant Jamaican women. BMC pregnancy and childbirth. 2008 Feb 28;8(1):8.

13. Faupel-Badger JM, Hsieh CC, Troisi R, Lagiou P, Potischman N. Plasma volume expansion in pregnancy: implications for biomarkers in population studies. Cancer Epidemiol Biomarkers Prevent. 2007 Sep;16(9):1720-3.

14. Mohamed AO, Hamza KM, Babker AM. Physiological changes in some hematological and coagulation profile among Sudanese healthy pregnant women. Int J Med Sci Public Health. 2016 Mar 1;5:525-8.

15. Abass RE, Omballi MM, Osman MI. Assessment of complete blood count in Sudanese pregnant women in different trimesters in Khartoum State. Eur Academic Res. 2016;IV(7):5960-4.

16. Milman N, Bergholt T, Byg KE, Eriksen L, Hvas AM. Reference intervals for haematological variables during normal pregnancy and postpartum in 434 healthy Danish women. Eur J Haematol. 2007 Jul;79(1):39-46.

17. Goswami TM, Patel VN, Pandya NH, Mevada AK, Desai KS, Solanki KB. Maternal anaemia during pregnancy and its impact on perinatal outcome. Int $\mathbf{J}$ Biomed Adv Res. 2014;5(02):99-102.

18. Canzoneri BJ, Lewis DF, Groome L, Wang Y. Increased neutrophil numbers account for leukocytosis in women with preeclampsia. Am J Perinatol. 2009 Nov;26(10):729-32.

19. Pughikumo OC, Pughikumo DT, Omunakwe HE. White blood cell counts in pregnant women in Port Harcourt, Nigeria. IOSR-JDMS. 2015;14(3):01-03.

20. Pitkin RM, Witte DL. Platelet and leukocyte counts in pregnancy. Jama. 1979 Dec;242(24):2696-8.

Cite this article as: Ahmed WMM, Khalid A, Musa OA. Effect of pregnancy on packed cell volume and total white blood cells count among Sudanese pregnant women attending antenatal care at Ribat University Hospital (Khartoum state). Int J Reprod Contracept Obstet Gynecol 2018;7:371-4. 